\author{
Santhi Corcoran* \\ Mary Immaculate College, Limerick, Republic of Ireland \\ Department of Learning, Society and Religious Education \\ https://orcid.org/0000-0002-1458-8365
}

\title{
Exodus, Exile and Resettlement: **Displaced children and families in Ireland and the challenges for state and educational facilities
}

\begin{abstract}
Where oppression, denial of culture, faith, identity, and language have been a significant part of a group's collective history, strong nationalistic and ethnocentric tendencies develop to protect and reinforce a threatened and diminishing sense of self $1,2,3$. Within such a context, policies and practices in schools and state towards newcomers may be problematic. The preferred position in government policies would be for assimilation into the host culture and adoption of its values, but this approach diminishes the values
\end{abstract}

Santhi Corcoran is a Lecturer with the Department of Learning, Society and Religious Education at Mary Immaculate College, University of Limerick, Ireland, and a Further Education tutor in Healthcare with Limerick and Clare Education and Training Board, Limerick, Ireland. She has a professional background and qualifications in Healthcare, Psychology, Adult and Community Education, Management and Social Studies, and provides training and consultancy in these areas.

** Refugees, Asylum Seekers and Migrant children and families are referred to as displaced in this paper in relation to displacement from home, land, culture, language, and family.

1 D. T. Ayton-Shenker, 'The Challenge of Human Rights and Cultural Diversity', New York: Backnote, United Nations Department of Public Information, 1995.

2 J. Cummins, Diverse Futures: Immigration, Education, and Identity in Changing Times, [in] Ed. P. O Duibhir, R. McDaid and A. O'Shea, All Changed? Culture and Identity in Contemporary Ireland, Dublin 2011, pp. 49-68

3 A. Horan, Nationalism, prejudice, and intercultural education, "Irish Teachers' Journal", 2(1): 2014. 
and culture of newcomersand underminestheprocessesofintegration ${ }^{4,5}$. This approach does not promote an environment where debate on inclusion, equality and identity can create a positive understanding of migration and diversity. Ireland, as part of the global world, will continue to receive new communities, and migration from both Europe and further afield. Therefore, education personnel at all levels need to be trained, inspired and competent when working with diversity ${ }^{6}$. The approach of schools towards diversity and the experience of immigrants can provide a key understanding of inclusion and exclusion in Irish society ${ }^{7}$. These can range from communication difficulties, to cultural practices and beliefs, racism experienced, isolation, and the hopes as well as aspirations of families and young people ${ }^{8,9}$. This paper explores, in the context of social justice and equality, issues of identity, needs, education, multiculturalism, acceptance and belonging for newcomers to Irish society, and the Irish education system's preparedness in supporting their children. It offers an overview of the Irish education system in terms of new arrivals, with a focus on challenges and implications for school systems.

Key words: Displaced, Inclusion, equality, diversity, school, integration.

4 H. K. Bhabha, Race, Time, and the Revision of Modernity: From the Location of Culture, London: Routledge, 1994, pp. 236-56.

5 R. Flecha, Modern and postmodern racism in Europe: dialogic approach and anti-racist pedagogies, "Harvard Educational Review", 69(2): 1999, pp. 150-171.

6 A. Bryan, and M. Bracken, Learning to Read the World? Teaching and Learning about Global Citizenship and International Development in Post Primary Schools, Dublin: Irish Aid, 2011.

7 D. Devine, Immigration and Schooling in the Republic of Ireland; Making a Difference?, Manchester: Manchester University Press, 2011.

8 N. Richman, In The Midst of The Whirlwind: A Manual For Helping Refugee Children, London: Save the Children \&Trentham Books, 1998.

9 G. Richards, and F. Armstrong, Teaching and Learning in Diverse and Inclusive Classrooms. Key Issues for New Teachers. Second edition, London: Routledge, 2016. 
"The stories a society tells about itself are a measure of how it values itself, the ideals of democracy and its future." - Henry Giroux, 1991

Ireland has within its own history experienced war, displacement, migration, and famine. These experiences have included discrimination, subjugation and long-term civil unrest for its own freedom. The indigenous inhabitants of this island have experienced within their collective memory the fear and distress of displacement, and the separation and loss of its people and future generations to migration ${ }^{10,11}$. Ireland has also experienced significant transformation in recent times, from a nation of migrants to one of new immigration ${ }^{12,13}$. The impact of the change that Irish society has faced in a relatively short period of time, and whether this Irish generation has been equipped to live in a diverse society, are issues that have yet to be addressed adequately ${ }^{14}$. Having experienced the denial of cultural values, faith and language in its history, strong nationalistic policies have developed to protect and reinforce its identity ${ }^{15,16,17}$. In most societies ethnicity, status, culture, socio-economic viability, and our faith/religion can sometimes be held as markers of our eligibility for acceptance or rejection within that society ${ }^{18,19}$. Entrenched within this are decades and even centuries of beliefs and values that are sometimes unwittingly ethno-

10 M. MacGreil, Pluralism and Diversity in Ireland. Prejudice and Related Issues in Early 21st Century Ireland, Dublin: The Columba Press, 2011.

11 J. Cummins, op. cit., pp. 49-68.

12 A. Bryan, The co-articulation of national identity and interculturalism in the Irish curriculum: Educating for democratic citizenship?, 1 (6), 2008. DOI: 10.1080/14748460801889894.

13 D. Faas, and W. Ross, Identity, diversity, and citizenship: A critical analysis of textbooks and curricula in Irish Schools, "International Sociology", 27:2012, p. 574.

14 R. Tormey, and J. Gleeson, Irish post-primary students' attitudes towards ethnic minorities, "Irish Educational Studies" 31(2): 2012, pp.157-173. R. Tormey, and J. Gleeson, Irish post-primary students' attitudes towards ethnic minorities, "Irish Educational Studies" 31(2): 2012, pp.157-173.

15 J. Cummins, op. cit., pp. 49-68.

16 M. MacGreil, op. cit.

17 A. Ugba, When 'Home' is Nowhere: Re-Assessing African Diasporic Experience in 21stCentury Ireland, [in] All Changed? Culture and Identity in Contemporary Ireland, op. cit., pp.71-81.

18 J. Cummins, op. cit., pp. 49-68.

19 M. Hickman, Re-Imagining Ireland: Ireland and The Irish Diaspora for the 21st Century, [in] ibid., pp. 85-102. 
centric and xenophobic. These values and beliefs are then incorporated into the language and communication that is applied socially and within standards and policies in education, the media and in political rhetoric. This lack of social and emotional sensitivity towards newcomers promotes segregation and not inclusion $20,21,22,23,24,25$.

The displaced are as diverse as the communities and societies that encapsulate our global world. Displacement can occur when, due to conflict or natural disasters, you are forced to flee due to fear for your life and that of your family. It includes those seeking safe havens due to persecution, discrimination, or prejudice ${ }^{26,27}$. These events can create homelessness whereby individuals, families and communities must leave for places of safety and security when at risk. They are then unable to return for a period or are officially considered as displaced by agencies such as UNHCR (United Nations High Commission for Refugees). Many of these communities face displacement with members of their family, but increasingly survivors include young children who are separated from those who would care for them. Sometimes this separation is permanent due to the inability of officials to locate next of kin or may be due to death during flight from areas of unrest ${ }^{28,29}$. This can cause long term mental

20 E. Said, Orientalism, New York: Pantheon, 1978.

21 H. Winant, Rethinking race in Brazil, "Journal of Latin American Studies", 24 (1): 1991, pp. 173-192.

22 F. J. Davis, Who is Black: One Nation's Definition, University Park: Pennsylvania State University Press, 1991.

23 T. Modood, Difference', Cultural Racism and Anti-Racism, [in] Ed. P. Werbner and T. Modood, Debating Cultural Hybridity: Multi-Cultural Identities and the Politics of Anti-Racism, London and New Jersey 1997, pp. 154-172.

24 Runnymede Trust, The Future of Multi-Ethnic Britain: The Parekh Report, London: Profile Books, 2000.

25 S. Elton-Chalcraft, V. Lander, L. Revell., D. Warner, and L. Whitworth, To promote or not to promote fundamental British values? Teachers'standards, diversity, and teacher education, "British Educational Research Journal", 43 (1): 2017, pp. 29-48.

26 N. Richman, op. cit.

27 UNHCR, 2017- http://www.unhcr.org/en-ie/1951-refugeeconvention-html, Accessed 16th December 2017.

28 N. Richman, op. cit.

29 R. Hinds, "A family belongs together." Refugees' experiences of family reunification in Ireland, Dublin: Oxfam Report, 2018. 
health difficulties due to anxiety and grief, which can affect resettlement in a new country and community ${ }^{30,31}$. This situation could happen to any or all of us. Therefore, the impact and consequences of displacement must be understood as a universal possibility and viewed with a compassionate and humanitarian lens. The requirements of the displaced are not easily defined. They are not a homogenous group, and their needs are as complex as their individual experiences of war, famine, persecution, bereavement, and loss. What defines them is their resilience and courage in the face of adversity, but equally their vulnerability in exile ${ }^{32}$. Displacement significantly disrupts social, economic, and household norms and the protection and security they provide. It creates a situation of risk, fear, and anxiety in everyday life, and therefore the basis for inequalities. Lack of finances, food, shelter, and the inability to access appropriate services to meet basic needs creates marginalisation and a sense of hopelessness and helplessness ${ }^{33,34}$. In resettlement, as in flight, most displaced individuals, families, and communities face stressors in their safe havens, in understanding systems, language and cultures, and in navigating processes that are complex and multiple ${ }^{35,36}$. This state of being creates stressors that have physical, psychological, and social impacts ${ }^{37,38}$. Displaced children need a sense of safety and security to cope with the uncertainty of their situation. Some challenges that children and their families face include the uncertainty and insecurity of their new environment, the complexities of the new language that

30 W. H. Sack, R. H. Angell, J. D. Kinzie, and B. Rath, The Psychiatric effects of massive trauma on Cambodian children; II, the family, the home and the school, "Journal of the American Academy of Child Psychiatry", 25: 1986, pp. 377-383.

31 R. Hinds, op. cit..

32 N. Richman, op. cit.

33 J. Carey-Wood, K. Duke, V. Karn, and T. Marshall, The Settlement of Refugees in Britain, London: HMSO, 1995.

34 N. Richman, op. cit.

35 C. Jones, and J. Rutter, Refugee Education: mapping the field, Stoke-on-Trent: Trentham Books, 1998.

36 N. Richman, op. cit.

37 Ibid.

38 A. Baylav, V. Beining, S. Corcoran, S. Donnelly, K. W. Kalialia, and J. Healey, Addressing the needs of the newly arrived, "In Rising East, The Journal of East London Studies", Vol. 2, No. 3., Ed. T. Butler, 1998. 
they must master to communicate and express their needs, and the challenges of their day to day life in a strange land ${ }^{39,40,41}$.

The challenges faced by these children, their families, the education systems and receiving societies must be addressed and improved upon. John Dewey and Paulo Freire are two educational thinkers and influencers who reimagined education and educational spaces as environments where potential would be cultivated, equality invested in and empowerment and emancipation the normative landscape of our everyday realm. $(165,166,167)$ Dewey described education as having the potential to develop progressive and well-rounded future citizens, and societies where diversity of skills and ability at all levels are celebrated. Freire saw classrooms as places of collaborative learning between teachers and students, and the process allowing for the mutual development of knowledge, skill, and social justice.

Taken together, the purpose of this paper is to offer an overview of the challenges in the education system in Ireland in terms of new arrivals, with a focus on challenges and implications for school systems. In order to do so, the paper begins by describing the specific context in Ireland with regards to displaced people and their needs, with an additional focus on the experience of children and resettlement. It then provides arguments for the importance of diversity in the education system, specifically that it is in these educational contexts that integration and understanding can be promoted. Finally, an emphasis on application is presented in terms of the preparation of teachers for these diverse classrooms. Preparation that empowers teachers who promote equality in the classroom, along with the role of school leadership in facilitating a system that supports equity of access and school communities where anti-racism values are practised. Therefore, the specific research problem that is addressed here relates to the need for a new paradigm in intercultural competence development, in preparing teachers for diverse and multicultural classrooms.

39 N. Richman, op. cit.

40 D. Devine, M. Kenny, and E. Macneela, Naming the 'other': Children's construction and experience of racisms in Irish primary schools, "Race, Ethnicity and Education", 2008, pp. 369385.

\footnotetext{
41 A. Horan, op. cit.
} 


\section{How does Ireland fare in its support of the displaced?}

Numerous studies have been conducted on the socio-economic impact of immigration in Ireland ${ }^{42}$, but fewer on the response of the Irish state to the needs of immigrants ${ }^{43}$. Work on issues of racism and institutional racism has been explored $^{44,45,46,47}$, while school attitudes and the accommodation of newcomer students have been researched within the primary and post-primary contex $t^{48,49}$, $50,51,52,53,54$. However, immigration research is mostly limited to the perspective and voice of the host researcher and not the Migrant, Refugee or Asylum Seeker. Therefore, this situation does not provide a platform for a broader and more nuanced perspective or debate on the experiences of Refugees, Asylum Seekers or Migrants in Ireland. Provision for Asylum Seekers remains structured around 'Direct Provision Centres', residential spaces housing both adults and children

42 A. Barrett, A. Bergin, and D. Duffy, The Labour Market Characteristics and Labour Market Impact on Immigrants in Ireland, Dublin: ESRI Seminar Paper, 2005.

43 D. Devine, op. cit.

44 L. Bond, F. McGinnity, and H. Russell, Making Equality Count. Irish and International Research Measuring Equality and Discrimination, Dublin: Liffey Press, 2010.

45 M. MacGreil, op. cit.

46 C. Kitching, and A. Curtin, Addressing the Concept and Evidence of Institutional Racism in Education in Ireland, [in] Ed. K. Kitching and A. Curtin, Proceedings of the Racism and Education Conference and Networking Event 2012, Cork 2012.

47 J. Carr, and A. Haynes, A clash of racialisations: The Policing of 'Race' and of Anti-Muslim racism in Ireland, "Critical Sociology", 2013.

48 D. Byrne, F. McGinnity, E. Smyth, and M. Darmody, Immigration and school composition in Ireland, "Irish Educational Studies", 29 (3): 2010.

49 M. Darmody, E. Smyth, D. Byrne, \& F. McGinnity, New Schools, New Systems: The experiences of immigrant students in Irish schools, [in] Ed. Z. Bekerrman, T. Geisen, Migration, Minorities, and Learning - Understanding Cultural and Social Differences in Education. Minorities and Education, London 2011, pp. 283-300.

50 A. Bryan, and M. Bracken, op. cit.

51 D. Devine, op. cit.

52 D. Byrne, and M. Darmody, 'Educational Careers of Migrant Students in Ireland'. Addressing the Concept and Evidence of Institutional Racism in Education in Ireland, [in] Proceedings of the Racism and Education Conference and Networking Event 2012, op. cit.

53 R. Tormey, and J. Gleeson, op. cit., p.157-173.

54 M. Parker-Jenkins, and M. Masterson, No Longer 'Catholic, White and Gaelic: schools in Ireland coming to terms with cultural diversity, "Irish Educational Studies", 32 (40): 2013, pp. 477-492. 
in restricted, managed and controlled environments where social and community interaction is limited ${ }^{55}$. Financial support is basic, with non-provision of educational and play/child-friendly spaces being the norm. The length of waiting times for immigration processes prevents meaningful development of social, economic, or educational experiences and progression in a new but also possibly permanent environment. Countries that provide safe havens and are signed up to the UN conventions that specify the rights and entitlements of children should not fall short of the actual promotion and delivery of these rights. Article 29 particularly advocates for the child to be provided with education that develops a child's personality and talents and respects the child's own cultural values ${ }^{56}$.

Refugees, Asylum Seeking and Migrant communities in Ireland hail from many parts of the world, including Europe, Eastern Europe, Latin America, Sub-Saharan Africa, West Africa, Asia, South East Asia, and the Middle East. In the recent Irish census (2016) ${ }^{57}$ the significant nationalities listed in terms of non-Irish population in the Republic of Ireland were, Polish (122,515), those from the United Kingdom $(103,113)$, Lithuania $(36,552)$, Romania $(29,186)$, Latvia $(19,933)$ and Brazil $(13,640)$. The figure estimated for non-Irish nationals living in the Republic of Ireland is 535,475. Mixed Irish and non-Irish households are estimated to be around 134,838 and those carrying dual nationalities are estimated at 104,784. Inward immigration to Ireland prior to 2016 is estimated at 83,346 , and 53,708 of these newcomers are non-Irish, a significant figure for a nation with a small landmass ${ }^{58}$.

Ireland as an island nation has experienced a dramatic shift in terms of its population evolving and becoming multicultural from a nation once perceived

55 KNASC, Irish Immigrant Support Centre, (2017), http://www.nascireland.org/campaigns-for-change/direct-provision/. Accessed 3rd January 2018.

56 Council of Europe, European Convention on Human Rights, 1947, www.cvce.eu/en/collections/unit.../aadf5a4c-2972-41e8-9d44-9d5d4edb8dd, accessed July 1, 2017.

57 Central Statistics Office (CSO) (2016), Census 2016: Migration and Diversity, Dublin: The Stationary Office.

58 The request for dual nationality has increased since April 2011 in Ireland and will clearly be an area of interest as Brexit negotiations develop between the United Kingdom and The European Union. Brexit (Britain's referendum to exit the European Union) has created an increase in applications and interest in obtaining Irish passports by British citizens, (The Guardian, 28th June 2016). Most British citizens living in the Republic of Ireland have up to this point been able to maintain their citizenship and live with full rights in the state. This may change with Brexit. 
as homogeneous ${ }^{59,60,61}$. This developing cultural change creates an impetus for this society to learn to co-exist and to build structures and generate systems that accommodate diversity. Cultural competence and culturally relevant pedagogy must be part of the education system and policies of a nation with a fast changing cultural, ethnic, and social landscape ${ }^{62,63,64,65,66}$.

\section{Needs of displaced communities}

Many new arrivals, particularly those from areas of war, conflict and famine have been subjected to difficult travel for freedom and safety. During their arduous and difficult exodus they would have faced a lack of food, shelter, and security, as well as poor access to health and social care services ${ }^{67}$. The impact of malnourishment, lack of sleep, anxiety, chronic illness from injuries, and the stress of relocation can take a toll on their health and well-being on resettlement ${ }^{68,69}$. The need for support services that encompass advice and information on their practical, physical, psychological, social, and educational needs are vital for resettlement ${ }^{70,71,72}$. Many Refugees and Asylum Seekers may see

59 R. Tormey, and J. Gleeson, op. cit., p.157-173.

60 D. Devine, op. cit.

61 A. Horan, op. cit.

62 C. Sleeter, How White Teachers Construct Race, [in] Ed. C. McCarthy, and W. Crichlow, Race Identity and Representation in Education, New York 1993, pp. 151-71.

63 G. Ladson-Billings, Toward a Theory of Culturally Relevant Pedagogy, "American Educational Research Journal", 32 (3): 1995, pp. 465-491.

64 D. Gillborn, Anti-racism. From policy to praxis, [in] B. Moon, S. Brown and M. Ben-Peretz (eds.), Routledge International Companion to Education, London, 2000, pp. 476-488.

65 D. Devine, op. cit.

66 R. Tormey, and J. Gleeson, op. cit., pp. 157-173.

67 UNHCR, 2017, op. cit.

68 N. Richman, op. cit.

69 H. McColl, K. McKenzie, and K. Bhui, Mental healthcare of asylum-seekers and refugees, "Advances in Psychiatric Treatment", 14: 2008, pp. 452-459.

70 N. Dagnino, Responding to the Psychosocial Needs of Refugee Children: A Multifaceted Approach, [in] M. McCallin (ed.), The Psychological Well-Being of Refugee Children; Research, Practice and Policy Issues, Geneva, 1992.

71 N. Richman, op. cit.

72 R. Hinds, op. cit. 
shelter, food, and immediate security as the most important factors. Health and well-being needs are not often seen as the most significant, as the basics of life take precedence. Unsupported and unrecognised health and mental health needs can have a serious impact on and create emotional obstacles to a new life. Therefore, all aspects of relocation and resettlement must be approached with equal priority, including appropriately trained and culturally responsive advocacy and interpretation services ${ }^{73}$. Health service provision for Refugees and Asylum Seekers remains uncoordinated in Ireland. There is a necessity for understanding, awareness, and training for health professionals in a country where the provision of mental health support should be reimagined. Mental Health services and therapeutic programmes must develop culturally sensitive approaches that are sympathetic to displaced communities' belief systems, gender roles and trauma experiences, and appreciate the importance of trust and value of treatments to the client, to ensure equity of access and uptake of services ${ }^{74,75}$. Mental health services in Ireland have yet to establish a comprehensive, specific provision for Refugees and Asylum Seekers who have experienced psychological and physical trauma from the impact of war and conflict. Whilst other nations with significant displaced populations, such as the United Kingdom, Canada, and Australia, have developed different models of care, these may not necessarily be the right fit for the communities in Ireland. Ireland needs to develop a system of care that works with its health infrastructure, the needs of the displaced groups arriving and settling here, and upskill their clinical and social care professionals to be competent in managing their psycho-social needs ${ }^{76}$.

\section{Children and resettlement}

Refugee and Asylum-Seeking Children who may have witnessed events or violence that happened to their families or others can present their trauma

73 N. Richman, op. cit.

74 H. McColl, K. McKenzie, and K. Bhui, op. cit., pp. 452-459.

75 HSE, The National Intercultural Health Strategy 2007-2012, Ireland: Health Service Executive, 2008.

76 Many of the support programmes and activities for Refugee and Asylum-Seeking families and adults in Ireland are provided by community organisations and NGO's (Non-governmental organizations). Many remain under-resourced to provide comprehensive support programmes or initiatives. 
in several ways which are not always obvious. Fear, anxiety, distrust, anger, aggression, nightmares, depression, and withdrawal are not uncommon as they try and make sense of their past, present and future worlds ${ }^{77,78,79,80}$. Their parents may be unable to respond to their needs due to their own trauma and distress $^{81,82}$. Their grief for the loss of the familiar, their family and a sense of home can create a profound sense of uncertainty and confusion. The lack of language skills in a place of new culture, values and behavioural system can be difficult to adjust to when their parents lack the same skills ${ }^{83,84,85}$.

Communication and meaningful interaction are vital to gain trust, but this becomes a barrier if language and cultural understanding is limited or nonexistent, due to a lack of well-resourced advocacy and interpretation provision $^{86,87}$. A translator is not necessarily a skilled interpreter, nor can they adequately provide advocacy in equal measure. These are skills that must be applied appropriately and meaningfully as per occasion and need. Cultural sensitivity and the willingness to see beyond just verbal language is a necessity for those who seek to work with individuals and families who have experienced immense trauma and grief and who may feel there is stigma associated with their experiences ${ }^{88,89,90}$. A lack of skill in working with newcomer communi-

77 N. Richman, op. cit.

78 A. Burnett, and Y. Fassil, Meeting the Health Needs of Refugees and Asylum Seekers in the UK: An information and Resource Pack for Health Workers, London: London Directorate for Health and Social Care/Department of Health, 2002.

79 NASC, Irish Immigrant Support Centre, (2017), op. cit.

80 R. Hinds, op. cit.

81 S. Melzack, Thinking about the Internal and External Experiences of Refugee Children in Europe, [in] Children, War and Persecution, Stifftung fur Kinder/UNICEF (ed.), Osnabruck 1995.

82 N. Richman, op. cit.

83 Ibid.

84 C. Jones, and J. Rutter, op. cit.

85 R. Hinds, op. cit.

86 H. McColl, K. McKenzie, and K. Bhui, op. cit., pp. 452-459.

87 G. Richards, and F. Armstrong, op. cit.

88 N. Richman, op. cit.

89 Idem, Communicating with Children; Helping Children in Distress, London: Save the Children, 1993.

90 H. McColl, K. McKenzie, and K. Bhui, op. cit., pp. 452-459. 
ties can and will do more harm than good for those already in a fragile state psychologically and emotionally. It can also create a sense of distrust in terms of information requested and collated by professionals ${ }^{91}$.

\section{Why diversity in education matters: Promoting integration and understanding}

Within the context of Europe, Ireland remains on the margins of the debate on migration and immigration, and the far-right anti-migrant rhetoric that has taken shape in France, Germany, Italy, the United States and the United Kingdom. Nationalism is often a product of colonisation and both occupation and fear of occupation by others. Educational spaces are therefore not necessarily neutral and can embody a society's own culture, fundamental values, practices, faith, and sense of national identity; they are representations of that society ${ }^{92}$. Inclusion and opportunity for displaced communities are vastly diminished if policies and practices in education, the first step towards financial and social mobility, prevent future achievement and potential to flourish. Schools and teachers are the gatekeepers to this opportunity $93,94,95$. In Ireland schools are mostly Catholic in terms of values and culture. There are limited alternative choices, with some multidenominational and Protestant faith schools. The teaching force is also mostly homogeneous in terms of ethnicity (White Irish), socio-economic status (middle class) and faith (Catholic or Protestant) ${ }^{96}$. Despite the recent census (2016) ${ }^{97}$, where the numbers of those who chose no faith has grown, Christenings, Communions and Confirmations are events that are still seen as sacrosanct in families. Schools support these rituals, which are part of the educational/curricular norm and can have a place of significance in

91 S. Melzack, Thinking about the internal and external experiences of refugee children in Europe, [in] Children, War and Persecution, op. cit.

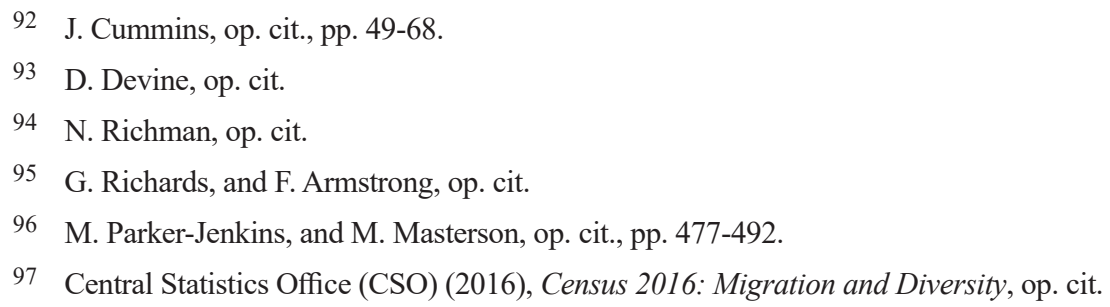


the school calendar. Similar accommodation is not always provided for the newcomer and their beliefs or representation of their faith ${ }^{98,99}$. Irish schools, however, generally accommodate the wearing of 'hijabs'(headscarves), unlike some Western European school systems (Parker-Jenkins \& Corcoran, 2018).

Education and accurate information are key to developing respect, compassion, and integration in communities. Ethical intercultural education promotes equality and human rights, and challenges prejudice and discrimination ${ }^{100}$. To promote this, teachers should be equipped with the skills and knowledge that enable them to be confident practitioners who can deal with complexity and diversity in the classroom ${ }^{101,102}$. Schools are the perfect communities in which to foster integration and understanding, where classrooms can be inclusive and sustainable environments, created by exploring issues that relate to diversity, displacement, loss, and rights. Subjects such as civic and citizenship studies, development education and social studies have a key role to play in this process ${ }^{103}$. Integration must be a process that involves the entire school community and the local community. Within their premises schools should aim to create a just, democratic, and equal community for all, a reimagined landscape that is inclusive ${ }^{104,105,106,107}$. The most therapeutic support that displaced children can experience is to become a part of the local community and attend a welcoming school where they can

98 D. Devine, op. cit.

99 ZC. Kitching, and A. Curtin, op. cit.

100 NCCA (National Council for Curriculum and Assessment), Guidelines on Intercultural Education in the Primary School, Dublin: NCCA, 2005.

101 C. Sleeter, op. cit., pp. 151-71.

102 R. Tormey, and J. Gleeson, op. cit., p.157-173.

103 A. Bryan, and M. Bracken, op. cit.

104 K. Lynch, The Hidden Curriculum: Reproduction in Education, A Reappraisal, Lewes: Falmer Press, 1989.

105 Idem, Equality in Education, Dublin: Gill \& Macmillan, 1999.

106 DES (Department of Education and Science) and Department of Education and the Office of the Minister for Integration, Intercultural Education Strategy, 2010-2015, Dublin: Stationery Office, 2010.

107 M. Hickman, op. cit., pp. 85-102. 
learn, and form friendships. The language, educational and social skills that they can attain will enable their participation in their new community $108,109$. Their sense of settlement and security can have a further positive impact on their parents and family and promote a sense of stability. Equally, their family will benefit from the support and understanding of their children's schools. Information and advice on new and often baffling school structures can be beneficial to this process ${ }^{110,111}$.

\section{Preparing teachers for diverse classrooms and the promotion of equity}

The requirement for preparation and training on the broader issues of diversity for all teachers, pre-service teachers, and those involved in the delivery of training and education at all levels is a necessity in our globalised societies. What is required cannot be a tokenistic rhetoric on change, or the delivery of training based on basic stereotyped cultural beliefs, practices, and behaviours, but a culturally relevant and sensitive pedagogy ${ }^{112,113}$. It should be a programme that enables educators and those they educate to make sense of their immediate culture and the global world, creating multiskilled future citizens ${ }^{114,115,116,117 .}$ Teachers and educators should be both participative and engaged in the process of building bridges, address their own assumptions and presumptions, and facilitate awareness that enables those they teach to understand diversity and

\footnotetext{
108 N. Richman, op. cit.

109 G. Richards, and F. Armstrong, op. cit.

110 K. Valtonen, Adaptation of Vietnamese refugees in Finland, "Journal of Refugee Studies",
} 7:1994, pp. 63-78.

111 N. Richman, op. cit.

112 G. Ladson-Billings, Toward a Theory of Culturally Relevant Pedagogy, op. cit., pp. 465491.

113 L. Darling-Hammond, and J. Bransford, Preparing Teachers for a Changing World: What Teachers Should Learn and Be Able to Do, San Francisco: Jossey-Bass, 2005.

114 M. Foucault, Discipline and Punish. The Birth of the Prison, translated by A. Sheridan, London: Penguin Books, 1977.

115 R. Deacon, Michel Foucault on education: a preliminary theoretical overview, "South African Journal of Education”, 26(2), 2006, pp. 177-187.

116 J. A. Banks, Diversity, group identity, and citizenship education in a global age, "Educational Researcher" 37 (3): 2008, pp. 129-139.

117 A. Bryan, op. cit. 
inclusion, and be attuned to their place within it ${ }^{118}$. Ireland at this point does not have any real representation of the growing diversity in its classrooms within the ranks of its teaching profession. Access to teacher education programmes for migrant teachers is currently being funded by the Department of Justice and Equality through the Office for the Promotion of Migrant Integration ${ }^{119}$. However, teachers who choose particularly to teach within the Primary sector will still be required to be proficient in Irish (Irish Heritage Language). Therefore, the exclusion criterion remains for those without proficiency in Irish, despite English being the mode of delivery in most schools. There is a need for deconstruction and dialogue in Ireland, on what education means, what it needs to provide, how it is delivered, who benefits, and what skills and tools are necessary for the nation's place within a global context ${ }^{120}$. Teacher education programmes should ensure that the areas covered include cultural diversity so that culturally competent teachers can 'ignite' migrant students' learning ${ }^{121}$. Furthermore, within the globalised world in which we live, teachers need to learn about, appreciate and respect the identities of their students, so that they can empower their individual learning and academic achievements ${ }^{122,}{ }^{123}$. Children are expected to fit into school systems, adhere to rules, and accept and promote school values, but equally schools must address, value and integrate the differences that children bring into the classroom and the identities that they present ${ }^{124,125,126,127 .}$

\footnotetext{
118 G. Richards, and F. Armstrong, op. cit.

119 Migrant Teacher Project, (2017). https://www.mie.ie/en/Research/, Migrant Teacher_Pro-
} ject, Accessed 16th December 2017.

120 M. MacGreil, op. cit.

121 Y. DeGaetano, and C. Espana, Cultural Competence in Education, New York: Center for Puerto Rican Studies at CUNY, 2010.

122 Ibid.

123 A. M. Villegas, and T. Lucas, Educating Culturally Responsive Teachers: A Coherent Approach, Albany: State University of New York Press, 2002.

124 J. King, Dysconscious Racism; Ideology, Identity, and the Miseducation of Teachers, [in] G. Ladson-Billings and D. Gillborn (eds.), Multicultural Education, London 1991.

125 C. Sleeter, op. cit., pp. 151-71.

126 G. Bhatti, Good, Bad and Normal Teachers. The Experiences of South Asian Children, [in] Asian Children at Home and at School, London: Routledge, 1999, pp. 178-206.

127 T. Modood, Difference, Cultural Racism and Anti-Racism, [in] Debating Cultural Hybridity: Multi-Cultural Identities and the Politics of Anti-Racism, op. cit., pp. 154-172. 
When a culturally and socially relevant pedagogy is applied to learning, it creates awareness, and contributes to the improvement, efficiency, and capability of learners ${ }^{128,129,130,131}$. Educators at every level should be taught to teach, assess, and be inspired and motivated when working within diverse classrooms ${ }^{132,133,134,135 .}$

\section{School leadership}

The proficiencies principals need to manage and lead schools in a rapidly changing social, cultural, and financial landscape can be complex and insurmountable ${ }^{136,137,138}$. Furthermore, they are expected to promote policies and practices that will ensure that equality and diversity are supported within their schools. They are also expected to create spaces that promote social justice and apply democratic approaches that will empower their pupils, teachers and school communities while being the leaders accountable for the success or failure of their schools. This creates immense pressures and a sense of responsibility that

128 K. Zeichner, Educating Teachers for Cultural Diversity, East Lansing: National Centre for Research on Teacher Learning, 1992.

129 S. Nieto, Critical Multicultural Education and Students'Perspectives, [in] Ed. S. May, Critical Multiculturalism, London 1999, pp. 191-215.

130 J. Landsman, and C. Lewis, White Teachers, Diverse Classrooms $2^{\text {nd }}$ Edition, Stylus Publishing, LLC, 2011.

131 M. A. Alsubaie, Examples of current issues in the multicultural classroom, "Journal of Education and Practice", 6 (10): 2015.117

132 M. Witsel, Teaching and Learning issues in the multicultural classroom, "Proceedings of Effective Teaching and Learning Conference”, 2013.

133 G. Ladson-Billings, Toward a Theory of Culturally Relevant Pedagogy, op. cit., pp. 465491.

134 A. Bryan, and M. Bracken, op. cit.

135 R. Tormey, and J. Gleeson, op. cit., pp. 157-173.

136 S. S. Takahashi, The Keeper of the house: Principal succession and the mending of the hearts, "Annual meeting of the American Educational Research Association", San Diego 1998.

137 B. M. Davidson, and D. L. Taylor, The effects of principal succession in an accelerated school, San Diego: Annual meeting of the American Educational Research Association, 1999.

138 B. Davies, The Essentials of School Leadership, 2nd Edition, London: Sage, 2009. 
can be overwhelming due to the multiple and often perplexing and continuously changing guidelines that they receive ${ }^{139,140,141,142,143}$. Within the context of such complexity, to create educational spaces that can support traumatised, displaced children with multiple needs can be challenging. Schools that are successful are often supported in learning and development for both teachers and pupils, but also where the leadership has authority and is fair, consistent, and democratic towards change ${ }^{144,145,146,147}$. This is promoted by the NCCA - (Irish National Council for Curriculum and Assessment), and within documents, toolkits and circulars produced by the Irish Department of Education and Skills to support intercultural classrooms and intercultural education ${ }^{148}$.

\section{Racism, equality, and educational spaces}

Discrimination and marginalisation can create social, health and educational inequalities within any society and contribute to the detriment of quality of life ${ }^{149}, 150$. Racism is often defined rather subjectively as prejudice relating

139 B. J. Caldwell, Strategic leadership, resource management and effective school reform, "Journal of Educational Administration", 36(5): 1998, pp. 445-461.

140 R. F. Elmore, Building a New Structure for School Leadership, Washington DC: Albert Shanker Institute, 2000.

141 J. Blasé, and J. Blasé, Shared Governance principals: The inner experience, "NASSP Bulletin", 83(606): 1999. pp 81-93.

142 K. S. Whitaker, Principal role changes and implications for Principalship candidates, "International Journal of Education Reform”, 8(4): 1999, pp. 352-362.

143 M. A. Copland, The myth of the super principal, "Phi Delta Kappan", 82 (7): 2001, pp. 528533.

144 W. Reese, Power and the Promise of School Reform, New York: Routledge, 1986.

145 M. W. Apple, Between Neo and Post; Critique and Transformation in critical educational studies, [in] Ed. C. A. Grant, Multicultural research: A Reflective Engagement with Race, Class, Gender and Sexual Orientation, London 1999, pp. 54-56.

146 J. P. Spillane, R. Halverson, and J. B. Drummond, Investigating school leadership practice: A distributed perspective, "Educational Researcher", 30 (3): 2001, pp. 23-28.

147 B. Davies, op. cit.

148 NCCA (National Council for Curriculum and Assessment), Guidelines on Intercultural Education in the Primary School, op. cit.

149 S. Fernando, Mental Health in a Multi-Ethnic Society. A Multidisciplinary Handbook, London: Routledge, 1996.

150 S. Fernando, and F. Keating, Mental Health in a Multi-Ethnic Society: A Multidisciplinary Handbook, Second Edition, London: Routledge, 2009. 
to the colour or ethnicity of the individual. In effect it should be addressed objectively in relation to ethnocentrism in a broader context such as language, culture, behaviour, religion, gender and sexuality within both political and social institutions ${ }^{156,152,153,154,155,156}$. Our sense of social justice and fair play does not always reflect a true sense of equity. It can be influenced by our own perception of who is deserving of it, and equally influenced by our identity, experience, values, beliefs, and the societal factors that inform us, and impacts our judgements. The imposition of the values and beliefs of the host country while not celebrating the different beliefs of the newcomer creates resentment and a devaluing of the culture of the newcomer ${ }^{157}$. Institutional racism has not been debated or explored adequately in Irish educational institutions ${ }^{158,159,160}$. This is particularly noticeable in the homogeneity of teaching staff in schools and higher educational institutions. Equality should not become a rhetoric of policy; rather it must be a process practised as equal respect for all groups and individuals ${ }^{161}$. This is a necessary reminder of the fact that try as we may, the system, staff, and modes of assessment in educational sectors in many countries, Ireland included, do not epitomise equality. The incorporation of faith- based cultural values, such as the requirement for Catholic

151 H. A. Giroux, Postmodernism, and the Discourse of Educational Criticism, [in] Ed. S. Aronowitz and H. A. Giroux, Postmodern Education: Politics, Culture, and Social Criticism, Minneapolis and Oxford 1991, pp. 57-86.

152 M. Omi, and H. Winant, On the Theoretical Status of the Concept of Race, [in] Race Identity and Representation in Education, op. cit., pp. 3-10.

153 G. Ladson-Billings, Just what is Critical Race Theory and what's it doing in a nice field like education?, "International Journal of Qualitative Studies in Education", 11 (1): 1998, pp. 7-24.

154 K. Lynch, Equality in Education, op. cit.

155 D. Gillborn, op. cit., pp. 476-488.

156 M. MacGreil, op. cit.

157 A. Bryan, and M. Bracken, op. cit.

158 N. Haran, and R. Tormey, Celebrating Difference, Promoting Equality; Towards a framework for intercultural education in Irish classrooms, 2002, Centre for Educational Disadvantage research, http://works.bepress.com/roland_tormey/30/, Accessed 3rd January 2018.

159 C. Kitching, and A. Curtin, op. cit.

160 K. Kitching, Taking responsibility for Race, Inequality and the Limitless Acts Required: Beyond 'good/bad whites' to the immeasurably whitened self, "Power and Education", 3 (2), 2011.

161 K. Lynch, Equality in Education, op. cit. 
baptismal certificates for school registration and holy communion programmes within the education system in Irish schools creates segregation between those who are part of the host culture and faith, and those who are not. Furthermore, the lack of cultural diversity within staff structures creates a vacuum in terms of cultural competence and sensitivity in working in multicultural classrooms. The process of adaptation is complex for displaced children without the added pressure of conforming to another's values, beliefs, and faith practices ${ }^{162,163}$. It is also a form of politicization of the teaching profession, whereby to collude in this process is also a form of racial discrimination towards the different other ${ }^{164}$.

\section{Conclusion}

In the context of ongoing waves of migration to Ireland and a demonstrated need to improve the experience of migrant children, it is imperative that educational spaces be equipped to support diversity and equity for all. Education and educational spaces have the potential to develop progressive and well-rounded future citizens, through collaborative learning and mutual development between teachers and students, and a process allowing for the mutual development of knowledge, skills, and social justice. Whether the Irish governing bodies and government equally aspire to these principles is a question that institutions and school leaderships must reflect on and champion for the sake of their students, teachers, and school communities. The change that must begin to take place in teacher education and in schools will not be achievable without an investment in political will and resources. That investment must be placed, within Ireland, in its teacher education institutions to lead in a reform that is long overdue. A reform that must address equality, equity of access, as well as the preparation of teachers and principals for diverse needs and multicultural classrooms. This should enable schools to promote and embrace diversity not just in their classrooms but also in their staffrooms. Equally, educational research and researchers must contri-

163 C. Kitching, and A. Curtin, op. cit.

164 S. Elton-Chalcraft, V. Lander, L. Revell., D. Warner, and L. Whitworth, op. cit., pp. 29-48. 
bute towards a movement for change and be collaborators with schools and communities as advocates for such change. That would truly be educational democracy, equality and social justice in action and access to and delivery of culturally responsive and empowering education for all.

\section{References}

Alsubaie, M. A. (2015). Examples of current issues in the multicultural classroom. Journal of Education and Practice, 6(10).

Apple, M. W. (1999). Between Neo and Post; Critique and Transformation in critical educational studies. In C. A. Grant (Ed.), Multicultural research: A Reflective Engagement with Race, Class, Gender and Sexual Orientation (pp. 54-56), London.

Ayton-Shenker, D. T. (1995). 'The Challenge of Human Rights and Cultural Diversity'. Backnote, United Nations Department of Public Information. New York.

Banks, J. A. (2008). Diversity, group identity, and citizenship education in a global age. Educational Researcher, 37(3), 129-139.

Barrett, A., Bergin, A., \& Duffy, D. (2005). The Labour Market Characteristics and Labour Market Impact on Immigrants in Ireland. Dublin: ESRI Seminar Paper.

Baylav, A., Beining, V., Corcoran, S., Donnelly, S., Kalialia, K. W., \& Healey, J. (1998). Addressing the needs of the newly arrived. In T. Butler (Ed.), In Rising East, The Journal of East London Studies Volume 2, No. 3.

Bhabha, H. K. (1994). Race, Time, and the Revision of Modernity: From the Location of Culture (pp. 236-56). London: Routledge.

Bhatti, G. (1999). Good, bad and normal Teachers. The experiences of South Asian children. [in] Asian Children at Home and at School (pp. 178-206). London: Routledge.

Blasé, J., \& Blasé, J. (1999). Shared Governance principals: The inner experience. NASSP Bulletin, 83(606), 81-93.

Bond, L., McGinnity, F., \& Russell, H. (2010). Making Equality Count. Irish and International Research Measuring Equality and Discrimination. Dublin: Liffey Press.

Burnett, A., \& Fassil, Y. (2002). Meeting the Health Needs of Refugees and Asylum Seekers in the UK: An information and Resource Pack for Health Workers. London: London Directorate for Health and Social Care/Department of Health. 
Bryan, A. (2008). The co-articulation of National Identity and interculturalism in the Irish curriculum: educating for democratic citizenship? London Review of Education, 1(6), 47-58. https://doi.org/10.1080/14748460801889894

Bryan, A., \& Bracken, M. (2011). Learning to Read the World? Teaching and Learning about Global Citizenship and International Development in Post Primary Schools. Dublin: Irish Aid.

Byrne, D., McGinnity, F., Smyth, E., \& Darmody, M. (2010). Immigration and school composition in Ireland. Irish Educational Studies, 29(3).

Byrne, D., \& Darmody, M. (2012). 'Educational Careers of Migrant Students in Ireland'. Addressing the Concept and Evidence of Institutional Racism in Education in Ireland. Proceedings of the Racism and Education Conference and Networking Event. K. Kitching, \& A. Curtin (Eds.), School of Education, University College Cork, Cork, Ireland.

Caldwell, B. J. (1998). Strategic leadership, resource management and effective school reform. Journal of Educational Administration, 36(5), 445-461.

Carey-Wood, J., Duke, K., Karn, V., \& Marshall, T. (1995). The Settlement of Refugees in Britain. London: HMSO.

Carr, J., \& Haynes, A. (2013). A clash of racialisations: The policing of 'race' and of Anti-Muslim racism in Ireland. Critical Sociology, 1, 21-40.

Central Statistics Office (2016), Census 2016: Migration and Diversity, Dublin, The Stationary Office.

Copland, M. A. (2001). The myth of the super principal. Phi Delta Kappan, 82(7), 528-533.

Council of Europe (1947). European Convention on Human Rights. https://www. cvce.eu/en/collections/unit.../aadf5a4c-2972-41e8-9d44-9d5d4edb8dd (accessed 1 July 2017).

Cummins, J. (2011). Diverse Futures: Immigration, Education, and Identity in Changing Times. In P. O. Duibhir, R. McDaid, \& A. O'Shea (Eds.), All Changed? Culture and Identity in Contemporary Ireland (pp. 49-68). Dublin.

Dagnino, N. (1992). Responding to the Psychosocial Needs of Refugee Children: A Multifaceted Approach, In M. McCallin (Ed.), The Psychological Well-Being of Refugee Children; Research, Practice and Policy Issues. Geneva.

Darling-Hammond, L., \& Bransford, J. (2005). Preparing Teachers for a Changing World: What Teachers Should Learn and Be Able to Do. San Francisco, JosseyBass. 
Darmody, M., Smyth, E. Byrne, D. \& McGinnity F. (2011). New Schools, New System: The Experiences of Immigrant Students in Irish Schools. In Z. Bekerrman, \& Geisen, T (Eds.), International Handbook of Migration, Minorities and Education - Understanding Cultural and Social Differences in Processes of Learning (pp. 283-300), Dordrecht Heidelberg London New York: Springer Science \& Business Media.

Davis, F. J. (1991). Who is Black: One Nation's Definition. University Park, PennsyIvania State University Press.

Davies, B. (2009). The Essentials of School Leadership, $2^{\text {nd }}$ Edition. London: Sage.

Davidson, B. M., \& Taylor, D. L. (1999). The effects of principal succession in an accelerated school. San Diego: Annual meeting of the American Educational Research Association.

Deacon, R. (2006). Michel Foucault on education: a preliminary theoretical overview. South African Journal of Education, 26(2), 177-187.

DeGaetano, Y., \& Espana, C. (2010). Cultural Competence in Education. New York: Centre for Puerto Rican Studies at CUNY.

DES (Department of Education and Science) and Department of Education and the Office of the Minister for Integration (2010). Intercultural Education Strategy, 2010 - 2015. Dublin: Stationery Office.

Devine, D., Kenny, M., \& Macneela, E. (2008). Naming the 'other': Children's construction and experience of racisms in Irish primary schools. Race, Ethnicity and Education, 11(4), 369-385.

Devine, D. (2011). Immigration and Schooling in the Republic of Ireland; Making a Difference?, Manchester: Manchester University Press.

Dewey, J. (1972). My pedagogic creed. In J. A. Boydston (Ed.), The early works of John Dewey 1882-1898. Vol. 5 (pp. 84-95). Carbondale: Southern Illinois University Press.

Elmore, R. F. (2000). Building a New Structure for School Leadership. Washington DC: Albert Shanker Institute.

Elton-Chalcraft, S., Lander, V., Revell, L., Warner, D., \& Whitworth, L. (2017). To promote or not to promote fundamental British values? Teachers' standards, diversity, and teacher education. British Educational Research Journal, 43(1), 29-48.

Faas, D., \& Ross, W. (2012). Identity, diversity, and citizenship: A critical analysis of textbooks and curricula in Irish Schools. International Sociology, 27, 574.

Fernando, S. (1996). Mental Health in a Multi-Ethnic Society. A Multidisciplinary Handbook. London: Routledge. 
Fernando, S., \& Keating, F. (2009). Mental Health in a Multi-Ethnic Society: A Multidisciplinary Handbook. Second Edition. London: Routledge.

Flecha, R. (1999). Modern and postmodern racism in Europe: dialogic approach and anti-racist pedagogies. Harvard Educational Review, 69(2), 150-171.

Foucault, M. (1977). Discipline and Punish. The Birth of the Prison. Translated by A. Sheridan. London: Penguin Books.

Freire, P. (1970). Pedagogy of The Oppressed. London: Penguin.

Freire, P. (1993). Paulo Freire, A Critical Encounter. P. McLaren, \& P. Leonard (Eds.). London: Routledge.

Gillborn, D. (2000). Anti-Racism. From Policy to Praxis, In B. Moon, S. Brown, \& M. Ben-Peretz (Eds.), Routledge International Companion to Education (pp. 476-488). London.

Giroux, H. A. (1991). Postmodernism, and the Discourse of Educational Criticism. In S. Aronowitz, \& H. A. Giroux (Eds.), Postmodern Education: Politics, Culture, and Social Criticism (pp. 57-86). Minneapolis and Oxford.

Haran, N., \& Tormey, R. (2002). Celebrating Difference, Promoting Equality; Towards a framework for intercultural education in Irish classrooms. Centre for Educational Disadvantage research. http://works.bepress.com/roland_tormey/30/ (accessed 3 January 2018).

Hickman, M. (2011). Re-Imagining Ireland: Ireland and The Irish Diaspora for the $21^{\text {st }}$ Century. In P. O Duibhir, R. McDaid, \& A. O'Shea (Eds.), All Changed? Culture and Identity in Contemporary Ireland (pp. 85-102). Dublin: Duras.

Hinds, R. (2018). "A family belongs together." Refugees' experiences of family reunification in Ireland. Dublin: Oxfam Report.

Horan, A. (2014). Nationalism, prejudice, and intercultural education. Irish Teachers' Journal, 2(1), 73-84.

HSE (2008). The National Intercultural Health Strategy 2007-2012. Ireland: Health Service Executive.

Jones, C., \& Rutter, J. (1998). Refugee Education: mapping the field. Stoke-on-Trent. Trentham Books.

King, J. (1991). Dysconscious Racism; Ideology, Identity, and the Miseducation of Teachers, In G. Ladson-Billings, \& D. Gillborn (Eds.), Multicultural Education. London. Kitching, K. (2011). Taking responsibility for Race, Inequality and the Limitless Acts Required: Beyond 'good/bad whites' to the immeasurably whitened self. Power and Education, 3(2), 164-178. 
Kitching, C., \& Curtin, A. (2012). Addressing the Concept and Evidence of Institutional Racism in Education in Ireland. In K. Kitching, \& A. Curtin (Eds.), Proceedings of the Racism and Education Conference and Networking Event 2012. University College Cork.

Ladson-Billings, G. (1995). Toward a Theory of Culturally Relevant Pedagogy. American Educational Research Journal, 32(3), 465-491.

Ladson-Billings, G. (1998). Just what is Critical Race Theory and what's it doing in a nice field like education? International Journal of Qualitative Studies in Education, 11(1), 7-24.

Lynch, K. (1989). The Hidden Curriculum: Reproduction in Education, A Reappraisal. Lewes: Falmer Press.

Lynch, K. (1999). Equality in Education. Dublin: Gill \& Macmillan.

Landsman, J., \& Lewis, C. (2011). White teachers, Diverse Classrooms $2^{\text {nd }}$ Edition. Stylus Publishing, LLC.

MacGreil, M. (2011). Pluralism and Diversity in Ireland. Prejudice and Related Issues in Early $21^{\text {st }}$ Century Ireland. Dublin: The Columba Press.

Melzack, S. (1992). Secrecy, Privacy, Survival, Repressive Regimes and Growing Up. Bulletin of the Anna Freud Centre, 15, 205-224.

Melzack, S. (1995). Thinking about the Internal and External Experiences of Refugee Children in Europe, In Stifftung fur Kinder/UNICEF (Ed.), Children, War and Persecution. Osnabruck.

McColl, H., McKenzie, K., \& Bhui, K. (2008). Mental healthcare of asylum-seekers and refugees. Advances in Psychiatric Treatment, 14, 452-459.

Migrant Teacher Project (2017). https://www.mie.ie/en/Research /Migrant Teacher_ Project (accessed 16 December 2017).

Modood, T. (1997). Difference', Cultural Racism and Anti-Racism. In P. Werbner, $\&$ T. Modood (Eds.), Debating Cultural Hybridity: Multi-Cultural Identities and the Politics of Anti-Racism (pp. 154-172). London and New Jersey.

NASC, Irish Immigrant Support Centre, (2017). http://www.nascireland.org/campaigns-for-change/direct-provision/ (accessed 3 January 2018).

NCCA (National Council for Curriculum and Assessment) (2005). Guidelines on Intercultural Education in the Primary School. Dublin: NCCA.

Nieto, S. (1999). Critical Multicultural Education and Students' Perspectives. In S. May (Ed.), Critical Multiculturalism (pp. 191-215). London.

Omi, M., \& Winant, H. (1993). On the Theoretical Status of the Concept of Race. 
In C. McCarthy, \& W. Crichlow (Eds.), Race Identity and Representation in Education (pp. 3-10). New York.

Parker-Jenkins, M., \& Masterson, M. (2013). No Longer 'Catholic, White and Gaelic: schools in Ireland coming to terms with cultural diversity. Irish Educational Studies, 32(40), 477-492.

Reese, W. (1986). Power and the Promise of School Reform. New York: Routledge.

Richards, G., \& Armstrong, F. (2016). Teaching and Learning in Diverse and Inclusive Classrooms. Key issues for new teachers. Second edition. London: Routledge.

Richman, N. (1993). Communicating with Children; Helping Children in Distress. London: Save the Children.

Richman, N. (1998). In The Midst of The Whirlwind: A Manual For Helping Refugee Children, London: Trentham Books Limited.

Runnymede Trust (2000). The Future of Multi-Ethnic Britain: The Parekh Report. London: Profile Books.

Sack, W. H., Angell, R. H., Kinzie, J. D., \& Rath, B. (1986). The Psychiatric effects of massive trauma on Cambodian children; II, the family, the home and the school. Journal of the American Academy of Child Psychiatry, 25, 377-383.

Said, E. (1978). Orientalism. New York; Pantheon.

Sleeter, C. (1993). How White Teachers Construct Race. In C. McCarthy, \& W. Crichlow (Eds.), Race Identity and Representation in Education (pp. 151-171). New York.

Spillane, J. P., Halverson, R., \& Drummond, J. B. (2001). Investigating school leadership practice: A distributed perspective. Educational Researcher, 30(3), 23-8.

Takahashi, S. S. (1998). The Keeper of the house: Principal succession and the mending of the hearts. Annual meeting of the American Educational Research Association. San Diego, CA.

Tormey, R., \& Gleeson, J. (2012). Irish post-primary students' attitudes towards ethnic minorities. Irish Educational Studies, 31(2), 157-173.

UNHCR (2017). http://www.unhcr.org/en-ie/1951-refugeeconvention-html (accessed 16 December 2017).

Ugba, A. (2011). When 'Home' is Nowhere: Re-Assessing African Diasporic Experience in $21^{\text {st }}$ Century Ireland. In P. O Duibhir, R. McDaid, \& A. O'Shea (Eds.), All Changed? Culture and Identity in Contemporary Ireland (pp. 71-81). Dublin: Duras.

Valtonen, K. (1994). Adaptation of Vietnamese refugees in Finland. Journal of Refugee Studies, 7, 63-78. 
Villegas, A. M., \& Lucas, T. (2002). Educating Culturally Responsive Teachers: A Coherent Approach. Albany: State University of New York Press.

Winant, H. (1990). Postmodern racial politics in the United States: Difference and inequality. Socialist Review, 90(1), 121-147.

Winant, H. (1991). Rethinking race in Brazil. Journal of Latin American Studies, 24(1), 173-192.

Whitaker, K. S. (1999). Principal role changes and implications for Principalship candidates. International Journal of Education Reform, 8(4), 352-362.

Witsel, M. (2003). Teaching and Learning issues in the multicultural classroom. Proceedings of Effective Teaching and Learning Conference. 6-7 November 2002, Brisbane.

Zeichner, K. (1992). Educating Teachers for Cultural Diversity. East Lansing: National Centre for Research on Teacher Learning. 